technically than their colleagues; and some fail to supervise surgeons in training adequately. These factors may compromise survival. The results support the contention that surgery for colorectal cancer should be undertaken by surgeons with a special interest in colorectal surgery or surgical oncology; this observation has important implications for surgical training.

At present considerable effort and resources are being poured into large multicentre studies of adjuvant chemotherapy and radiotherapy in an effort to provide marginal improvement in survival of patients with colorectal cancer. If by more meticulous attention to detail the results of surgery could be improved, and our results suggest that this would not be difficult, the impact on survival might be greater than that of any of the adjuvant therapies currently under study.

This study was made possible by the foresight of Professor $\mathrm{L} \mathrm{H}$ Blumgart and $\mathrm{Mr} \mathrm{C}$ B Wood, who established the colorectal cancer follow up clinic in 1974. The original data collection was funded by Cancer Research Campaign.
1 Fielding LP, Stewart-Brown S, Blesovsky L, Kearney G. Anastomotic integrity after operations for large-bowel cancer: a multicentre study. $B M J$ 1980;281:411-4

2 Phillips RKS, Hittinger R, Blesovsky L, Fry JS, Fielding LP. Local recurrence following "curative" surgery for large bowel cancer: I. The recurrence following "curative" surg

3 McArdle CS, Hole D, Hansell D, Blumgart LH, Wood CB. Prospective study of colorectal cancer in the west of Scotland: ten-year follow-up. Br f Surg of colorectal cance
$1989 ; 77: 280-2$

4 Kaplan EL, Meier P. Nonparametric estimation from incomplete observations. fournal of the American Statistical Association 1958;53:457-81.

5 Breslow NE, Day NE. Statistical methods in cancer research. Vol II - The design and analysis of cohort studies. Lyons: International Agency for Research in Cancer, 1987. Scientific publication No 82.

6 Cox DR. Regression models and life tables. Journal of the Royal Statistical Society $(B)$ 1972;34:187-220.

7 Ausobsky JR, Evans M, Pollock AV. Does mass closure of midline laparotomies stand the test of time? A random control clinical trial. Ann R Coll Surg Engl 1985;67:159-62.

8 Shandall A, Lowndes R, Young HL. Colonic anastomic healing and oxygen tension. Br f Surg 1985;72:606-9.

9 Quirke P, Purdy P, Dickson MS, Williams NS. Local recurrence of rectal adenocarcinoma due to inadequate surgical resection. Histopathological study of lateral tumour spread and surgical excision. Lancet 1986;ii:996-8.

10 Buck N, Devlin HB, Lunn JN. The report of the confidential enquiry into perioperative deaths. London: Nuffield Provincial Hospital Trust/King's Fund, 1987

(Accepted 25 April 1991)

\section{Golf related head injuries in children}

\section{R A Smith, S Ling, F W Alexander}

Department of Paediatrics,

Newcastle General

Hospital, Newcastle upon

Tyne NE4 6BE

R A Smith, MRCP, senior registrar

$\mathrm{S}$ Ling, $\mathrm{MB}$, senior house

officer

F W Alexander, FRCP,

consultant

\section{Correspondence to:}

Dr Alexander.

BMF 1991;302:1505-6 year.

\section{Patients, methods, and results}

Golf is the commonest cause of serious sports related head injuries in children, despite it being a predominantly adult game. ' Little attention, however, has been given to how the injuries actually occur. We report a series of children with head injuries due to golf who presented to a regional neurosurgical centre over one

We studied the case notes of all children admitted to our hospital over one year with head injuries. The hospital is a regional referral centre for children with head injuries. Jennett and Murray's definition of head injury was used. ${ }^{2}$ Where the details of the cause of injury were incomplete further information was obtained by contacting the parents.

In all, the case notes of 232 children were studied ( 139 boys and 93 girls; mean (SD) age $6 \cdot 7$ (4.33) years). Forty one children were referred from outside Newcastle.

The causes of the head injuries fell into four main categories: 113 were due to falls; 84 to road traffic accidents; 27 to sports injuries, including leisure related activities; and eight to non-accidental injury.

Of the 27 cases of sports related head injuries, 11 were associated with golf; five with skateboards; five with football; three with horse riding; and one each with swimming, ice skating, and kite flying. The 11 children with golf associated injuries were all boys (mean age $9 \cdot 89(2 \cdot 84)$ years). Of these, nine had skull fractures; the table gives details of the head injuries. Seven patients required elevation of the depressed skull fracture under general anaesthesia. None required admission to the intensive care unit. All were clinically well on discharge from hospital. The mean (range) duration of inpatient stay was $5 \cdot 18$ (1-8) days.

Nine of the children were injured when standing behind another child swinging a club; the head was struck on either the backswing or the follow through. Two children were hit on the head by golf balls struck by other children. In seven of the accidents the children had borrowed a golf club and were playing in either parkland or local fields. In one case the child had found the club in a field. Only one of the accidents occurred on a golf course; another occurred at the practice range of a course, and a third on a crazy golf course. On no occasion was play supervised by an adult.

Details of golf related head injuries in 11 boys

\begin{tabular}{|c|c|c|}
\hline Case No & $\begin{array}{c}\text { Age } \\
\text { (years) }\end{array}$ & Injury \\
\hline 1 & 8 & Depressed compound left frontal skull fracture \\
\hline 2 & 10 & Depressed compound right parietal skull fracture \\
\hline 3 & 6 & Depressed compound left orbital ridge skull fracture \\
\hline 4 & 10 & $\begin{array}{l}\text { Depressed compound left temporal skull fracture. } \\
\text { Extradural haematoma requiring left frontal } \\
\text { craniotomy and evacuation }\end{array}$ \\
\hline 5 & 13 & Depressed compound left supraorbital skull fracture \\
\hline 6 & 12 & Depressed compound right parietal skull fracture \\
\hline 7 & 14 & $\begin{array}{l}\text { Depressed compound right parietal skull fracture. } \\
\text { Cerebral contusion on computed tomography }\end{array}$ \\
\hline 8 & 10 & Deep laceration to forehead \\
\hline 9 & 6 & Depressed compound left parietal skull fracture \\
\hline 10 & 6 & Cephalhaematoma (left frontoparietal region) \\
\hline 11 & 14 & Depressed compound right frontoparietal skull fracture \\
\hline
\end{tabular}

\section{Comment}

In our series $40 \%$ of the sports related head injuries, $50 \%$ of all the depressed skull fractures, $18 \%$ of all skul fractures, and $4 \cdot 7 \%$ of admissions were associated with golf. Strang et al found that the proportion of head injuries that were sports related in all patients attending Scottish accident departments was $12 \%$, and for children under 15 years $21 \% .^{3}$ These injuries accounted for $14 \%$ of admissions to general surgical wards and $7 \%$ of admissions to a regional Scottish neurosurgical unit. ${ }^{2}$ Neither of these studies gave a breakdown of the sports concerned.

In a study that did not include children at play only $2.7 \%$ of 1900 admissions to a regional head injury unit were due to sports injuries. ${ }^{1}$ Golf was the commonest associated sport, causing $27 \%$ of all sports injuries. All were in boys under 16 (mean age 10). In a study of 400 patients with depressed skull fractures, sporting injuries accounted for $9 \%$, with golf by far the commonest associated sport. The fact that the other studies included adults probably explains the differences compared with our study in the incidence of golf related injuries.

While golf is a predominantly adult game, the mean age of the subjects with head injuries was about 10 years in both our study and in that of Lindsay et al.' Most of our patients were playing around with golf 
clubs as opposed to playing golf properly. It is not a dangerous sport if played properly. However, in the hands of children playing unsupervised, golf clubs are potentially lethal weapons. We recommend that children are supervised at all times when playing with golf clubs and that this should be done on a golf course.
1 Lindsay $\mathrm{KW}$, McClatchic G, Jennett B. Serious head injury in sport. B.Mf $1980 ; 281: 789-91$

2 Jennett B, Murray A. Head injuries in Scottish hospitals. Scottish head injury management study. Lancet 1977;ii:696-8.

3 Strang I, MacMillan R. Jennett B. Head injuries in accident and emergency departments at Scottish hospitals. Injury 1978;10:154-7.

4 Millar JD, Jennett WB. Complications of depressed skull fracture. Lancet 1968:ii:991-5.

(Accepted 7 7une 1991)

\section{Intravenous drug misuse among prison inmates: implications for spread of HIV}

\section{Stephen Dye, Chris Isaacs}

St Mary's Hospital Medical School, London W2 1PG Stephen Dve, medical student Chris Isaacs, medical student

Correspondence to: Mr S Dye, c/o Dr A J Pinching, Department of Immunologv, St Mary's Hospital Medical School, London W2 1 PG

B.MF 1991;302:1506
Although the Prison Reform Trust estimated in 1988 that 350-500 prisoners in England and Wales were infected with HIV,' only 63 were known to be positive for HIV antibody in 1989.' Some indication of intravenous drug misuse within British prisons has come from surveys of former prisoners while outside prison (K Dolan et al, unpublished data). ${ }^{3}$ No definitive research has been reported from within the British prison system. As Edinburgh has a high background rate of HIV infection among intravenous drug misusers we conducted a pilot survey of inmates in an Edinburgh prison to characterise intravenous drug misuse and risk of HIV infection within prison.

\section{Subjects, methods, and results}

The study was performed in Saughton Prison, Edinburgh, which houses about 500 male prisoners in different halls according to length of sentence; many inmates had been sentenced or were on remand for drug related offences. We carried out structured interviews consisting of personal questions and questions related to drug misuse and HIV infection after distribution to all inmates of a letter explaining the study; three halls were excluded because of time constraints. Volunteers informed their gallery officer if they wished to participate, but only we and the prisoner were present at interview.

Many drug users complained about their treatment in prison; others may not have volunteered because of worries over confidentiality, thus the sample may be unrepresentative of the prison population. Random selection was thought likely to introduce bias because of refusals. There were also obvious shortcomings in using self reported behaviour and HIV status. The study, therefore, in giving a glimpse of the behaviour of intravenous drug misusers in prison, identified the nature of the problem rather than gave a strict estimate of the prevalence of HIV or of risk behaviour.

In all, 123 inmates were interviewed $(32 \%$ of the available prison population), of whom 43 (35\%) admitted to having previously injected drugs. Twenty nine $(24 \%$ of the sample and $67 \%$ of the injectors) had injected drugs in prison. The table gives a breakdown of the responses. Drug injecting in prison was more common in short term and remand inmates than in long term prisoners. Forty nine $(40 \%)$ of the study group had been tested for HIV; of these, 15 had never injected drugs, and 13 reported themselves as being HIV positive. Four prisoners had shared needles but had never been tested. The prevalence of HIV infection was significantly higher among short term prisoners $\left(\chi^{2}=6 \cdot 72, \mathrm{p}<0 \cdot 01\right)$.

A total of 42 out of 43 intravenous drug misusers had injected outside prison, of whom $38(90 \%)$ had shared needles outside prison, 29 out of 43 had injected in prison, of whom $22(76 \%)$ had shared needles inside prison. Forty one inmates had shared needles at least once either inside or outside prison. Of the 13 inmates positive for HIV antibody, 12 had injected while in prison and 11 had shared needles in prison. This compares to the $30 \mathrm{HIV}$ negative or untested intravenous drug misusers, of whom 17 had injected and 11 had shared needles in prison. Of the 13 HIV positive inmates, six reported taking more oral drugs and injecting less both inside and outside prison than in the past, emphasising the changing pattern of drug misuse within the Lothian area. ${ }^{+}$

Data on intravenous drug misuse and HIV antibody status by category of prisoner

\begin{tabular}{lccccc}
\hline Category & $\begin{array}{c}\text { No of } \\
\text { inmates }\end{array}$ & $\begin{array}{c}\text { No } \\
\text { questioned }\end{array}$ & $\begin{array}{c}\text { No(\%) } \\
\text { intravenous } \\
\text { drug misusers }\end{array}$ & $\begin{array}{c}\text { No(\%) } \\
\text { injecting }\end{array}$ & $\begin{array}{c}\text { No } \\
\text { in prison for HIV }\end{array}$ \\
\hline Short term & 92 & 40 & $17(43)$ & $13(33)$ & 8 \\
Remand & 83 & 24 & $13(54)$ & $8(33)$ & 2 \\
Holding $\dagger$ & 78 & 22 & $5(23)$ & $4(18)$ & 2 \\
Long term $\ddagger$ & 64 & 14 & $2(14)$ & $2(14)$ & 1 \\
Served $>5$ years $\$$ & 62 & 23 & $6(26)$ & $2(9)$ & 0 \\
\hline Total & 379 & 123 & $43(35)$ & $29(24)$ & 13 \\
\hline
\end{tabular}

* Sentence of $<18$ months.

†Inmates at beginning of sentences of $>18$ months.

$\ddagger$ Sentence of $>18$ months.

$§$ Figures for one of two accommodation halls (plus one inmate from the other).

\section{Comment}

This study underlines the fact that intravenous drug misuse occurs to a worrying degree in prisons. We found that such behaviour is particularly a feature of short term and remand prisoners and that the prevalence of HIV infection was higher in short term inmates. This is probably because drug related offences mainly carry sentences of less than 18 months. Many remand prisoners were awaiting trial for similar offences. Furthermore, as more visits are allowed to remand prisoners there is a greater opportunity for obtaining drugs.

Although our study is unlikely to be representative of all prisons and may also comprise a somewhat skewed sample, it provides a valuable insight into the increasing problem of HIV and injecting drug misuse in prisons. To begin to tackle this problem further research on a much wider scale is required to document the extent of HIV risk activity within prisons and to determine optimal means of intervention to reduce the risk.

We thank all the prison staff at Saughton for their permission to conduct this study and their welcome. We also thank the inmates who volunteered and Dr A J Pinching for his help and advice. Financial help was provided by the Aids Virus Education Research Trust.

1 Prison Reform Trust. HIV, AIDS and prisons. London: Prison Reform Trust, 1988.

2 British Medical Association Foundation for AIDS. HIV and AIDS in prisons. London: BMA, 1989. (Parliamentary factsheet 7 .)

3 Carvell ALM, Hart GJ. Risk behaviours for HIV infection among drug users in prison. BMF 1990;300:1383-4.

4 Skidmore CA, Robertson JR, Robertson AA, Elton RA. After the epidemic follow up study of HIV seroprevalence and changing patterns of drug use. BMF 1990;300:219-23.

(Accepted 22 March 1991 